\title{
The Comparison of Language Learning Strategies and Reading Comprehension of Iranian EFL Students Taking Web-based and Face-to-face Instruction
}

\author{
Behzad Ghonsooly \\ English Department, Ferdowsi University of Mashhad, Iran \\ Zari Sadat Seyyedrezaie (corresponding author) \\ Ferdowsi University of Mashhad, International Campus, Iran
}

\begin{abstract}
This study investigated language learning strategies used by EFL web-based learners and face-toface learners. It also examined the difference between pre-test and post-test reading comprehension scores of EFL students who were exposed to web-based and face-to-face instruction. The participants of the study were 200 Iranian EFL university students. They were randomly assigned into two groups, 100 students in one group taking web-based instruction and 100 students in the other group taking face-to-face instruction. The students took a 50-item translated version of Strategy Inventory for Language Learning and a test of reading comprehension. This scale and the reading comprehension test were given as the pre-test and post-test to all students. During the treatment, summarization-strategy training was used to promote the learning process. The result of an independent samples $t$-tests revealed that there was no significant difference between the two groups of learners regarding their preferences for language learning strategies. Moreover, the result of a paired samples t-test indicated that there was significant difference between pre-test and post-test reading comprehension scores of EFL students who were exposed to face-to-face instruction. However, there was no significant difference between pre-test and post-test reading comprehension scores of EFL students who were exposed to web-based instruction.
\end{abstract}

Index Terms - language learning strategies, reading comprehension test, web-based instruction, face-to- face instruction

\section{INTRODUCTION}

During the past several years, computers and new technologies have become widespread in society. Accordingly, the number of people using computers and computer software daily for recreational, educational, and vocational purposes has increased, and knowing how to use computers has become a basic and indispensable skill. Perhaps one area of society that is noticeably influenced by computer technology is education, specifically in educational systems, students need to be computer literate in order to achieve success in a technologically-advanced society (Seyyedrezaie, Ghapanchi, \& Seyyedrezaie, 2013).

For understanding the effect of technology on education, formal education should be taken into account. In the formal education, there are some factors including systematic instruction, teaching, and training by professional teachers. In such known traditional form of education, teachers apply many different techniques for their teaching. Recently, online education is gaining popularity as an effective medium. "Online learning which is sometimes called WBI uses the attributes and resources of the World Wide Web to create a meaningful learning environment where learning is fostered and supported" (Khan, 1997, p. 6). Web-based instruction is a home-based learning and often emphasizes the value of distance learning and communication among the learners and their peers. The ways learners learn, remember, and process information has become the main concern of researchers in recent years. Most of the recent studies claim that technology is an increasingly influential factor which changes the face of the education (Khan, 1997; Lam, 2009). The teachers of e-learning seek guidance on pedagogical aspects of teaching, learner-focused and learning activities, and learning contexts which are provided with electronic technologies (Beethman, 2003).

In the case of language learning strategies, Littlewood (1996) holds the view that, because there are a lot of information to be acquired in a course of study, learners usually apply some language learning strategies consciously or even unconsciously in order to perform the tasks and process the new input. The application of language learning strategies is an indispensable part of a language learner's development. "The term strategies in second language learning sense, has come to be applied to the conscious moves by second language speakers intended to be useful either in learning or using second language" (Cohen, 1998, p.1). Oxford and Nyikos (1989) mention that selection of suitable 
language learning strategies makes learners to take responsibility for their own learning by increasing learner autonomy, independence, and necessary attributes for life-long learning.

Moreover, there are some basic factors including learners' goals, language proficiency, level of motivation, personality traits, and general learning styles which affect the selection and use of language learning strategies (Wenden \& Rubin, 1987; O’Malley \& Chamot, 1990).

Regarding all the existing factors which influence language learning strategy use, it is considered that the educational system under which the learners develop L2 communicative abilities affects the choice and use of learning strategies.

In the investigation of the role of strategies, one of the areas that has attracted much of the attention of researchers is reading skill. Learners tend to apply a variety of strategies while reading in order to understand the text.

Some might consider summarization as a kind of reading strategies would be an effective strategy to smooth the progress of the cognitive process of comprehension. Summarization is an effective learning strategy that can give students a hand to construct and retain enough summary of important points of text (Kintsch \& van Dijk, 1978, cited in Pakzadian, 2012).

In this respect, the purpose of the present study is to investigate whether there is any significant difference between post-test scores of web-based learners and face-to-face learners with regard to their preferences for language learning strategies, as well as whether there is any significant difference between pre-test and post-test reading comprehension scores of EFL students who were exposed to web-based and face-to-face instruction.

To fulfill the purpose of this study, the following research questions were addressed.

1. Is there any significant difference between post-test scores of web-based learners and face-to-face learners with regard to their preferences for language learning strategies?

2. Is there any significant difference between pre-test and post-test reading comprehension scores of EFL students who were exposed to web-based and face-to-face instruction?

\section{LITERATURE REVIEW}

\section{Web-based and face to face instruction}

Delivery of the education has changed throughout the history. Nowadays, there are two main delivery methods: faceto-face instruction and web-based instruction (Lam, 2009). In the industrial era, the main delivery method for instruction has been face-to-face (Lam, 2009). Olson and Wisher (2002) stated that in the traditional face-to-face method, the instructor can devote time to the learners, learners can interact with other learners and with the instructor, and immediate feedback is plausible. On the other hand, web-based instruction (WBI) is becoming a desirable training option in both industry and higher education. The term web-based education traces back to distance and virtual learning. Sampson (2003, cited in Adegbile \& Oyekanmi, 2009) declared that today, the term distance education is mostly used to describe courses where most of the interactions between teachers and students take place electronically through audio, video, chat, e-mail, videoconferences or internet platforms. According to Clark (1994, cited in Luthans, Avey, Patera, 2008), the mere application of Web-based instruction has no real value with regard to learning outcomes. Nevertheless, it has been proposed that students' performance improvements are the result of the advantages of WBI for school and faculty (Goldstein \& Ford, 2002; Welsh, Wanberg, Brown, \& Simmering, 2003, cited in Aguinis \& Kraiger, 2009).The structure of a strategic reading instruction component of English for professional purposes course in a technologyenhanced environment was analyzed by Dreyer and Nel (2003). According to their study, the subjects who were trained on reading strategies in the technology-enhanced environment got higher scores on three reading comprehension measures than did the subjects in the control group.

The results of Biggs, Simpson, and Walker (2006, cited in Senn, 2008)'s study revealed that online students receive lower instructor support and student interactions in an online instruction. On the other hand, Lock (2006) found out that cooperative work made online learners more successful and motivated than when they worked individually.

\section{Reading and language learning strategies}

In the process of learning, learning strategies play a prominent role. The appropriate use of learning strategies can result in increased foreign/second language proficiency. Applying certain strategies in language learning including reading skill is important because they are tools for active and self-directed involvement. Appropriate learning strategies lead to improvement of proficiency and self-confidence which become prerequisites for communicative competence as the main goal of language learning.

Reading strategies are complemented by language learning strategies. Several authors have provided definitions and taxonomies for learning strategies (O’Malley and Chamot, 1990; Oxford, 1990, cited in Asgari \& Mustapha, 2011). Oxford (1990) defined leaning strategies as "steps taken by students to enhance their own learning [which] are especially important for language learning because they are tools for active, self-directed involvement, which is essential for developing communicative competence" (p. 1). Even if the reading comprehension course does not aim at developing such communicative competence, the use of language learning strategies as declared by Oxford (1990) helps improve students' self-confidence and these reading strategies approach assist the learner to apply a learning strategy to solve problems when trying to understand a text. The learner relies on textual elements and his/her background knowledge to interact with the text.

Effect of Summarization strategies on Comprehension 
Summary writing is a mixture of reading and writing. Writing a summary of a text can help learners connect main points of ideas, process thoughts, rephrase and restructure them in their own words (Perin, 2002, cited in Pakzadian, 2012). Graham and Hebert (2011) investigated the reciprocal relationship between writing and reading to see whether writing activities have an impact on reading activities. They declared that having students write about what they have read simply will improve their reading abilities.

In many studies, teaching students how to use summarization strategies are considered to have significant impact on their comprehension (Doctorow, Wittrock, \& Marks, 1978; Wittrock\& Alesandrini, 1990). Wittrock and his colleagues concluded that the process of summarizing helps readers make relations among concepts of a text and relate these concepts to prior knowledge. Other studies suggest that summarization can help readers to pay attention to main information and therefore improve comprehension ( Anderson \& Armbruster, 1984; Pearson \& Fielding, 1991).Others have noticed that summarization improves comprehension by promoting self testing during reading and apply strategies to remedy comprehension failures (Palinscar \& Brown, 1984; Paris\& Lindauer, 1982).

\section{METHOD}

\section{A. Participants}

The participants of the present study were 200 Iranian freshman male (94) and female (106) EFL students chosen out of 225 students based on their Preliminary English Test (PET ) language proficiency test scores. The EFL students were from four Islamic Azad universities. The participants belonged to both genders and aged from 18 to 24 years old. They were all freshman students since they had to have passed the reading courses 1 and 2. The reason for this was to ensure that they had enough knowledge and background for understanding different types of reading comprehension texts. Also, they had different computer experiences. For example, some students had considerable experience using computers and software applications making presentations, and writing reports. It should be noted that most of their courses were held in traditional classrooms. But they had experienced some courses which included blended learning in the way that they were supposed to submit their assignments to their professors via email. Moreover, most of them did not have any experience of web-based instruction. But some of them had participated in some web-based classes which were not for teaching a foreign language. In this study, the participants were randomly assigned into two groups. There were 100 students in one group benefiting from web-based instruction and 100 students in the other group benefiting from face-to-face instruction. To reduce learners' anxiety and maximize learning, one face-to-face orientation was conducted for the online learners before the first session.

\section{B. Instrumentation}

The instruments that were utilized in this study were the Preliminary English Test (PET), a translated version of Strategy Inventory for Language Learning (SILL), and a test of reading comprehension.

a. Preliminary English Test (PET)

The present study was conducted with 200 EFL university students chosen out of 225 students based on their language proficiency test scores. A 67-item standard PET test, released by Cambridge ESOL exam (copy right 2004), was administered to evaluate the participants' general English proficiency level. The proficiency test PET (Preliminary English Test, 2004) is a second level Cambridge ESOL exam for the intermediate level learners. The test includes three sections because the researcher could not conduct the speaking section due to practicality issues.

b. Strategy Inventory for Language Learning (SILL)

A translated version of Strategy Inventory for Language Learning (SILL) adopted from Hasanpour (1999) was used to access the frequency with which language learners use each learning strategy. SILL consists of 50 likert-type items including 6 subscales.

\section{c. The Reading Comprehension Test}

The test of reading comprehension was composed of 3 passages titled "woman in ancient societies, crime, and history of religion," followed by multiple-choice format reading comprehension tests (Tahririan, 1996). Each passage contains almost 100 words. Also they were designed for intermediate level learners.

d. The Reading Comprehension Text

Five passages entitled "computer games, colors, looking for being in shape, a mysterious triangle, and luck," were selected from Live Reading developed by Yazdani Moghaddam, Seyyedrezaie, Rajabi, and Barani (2008) on the basis of the students' current level of mastery of the English language and their presumed interest. Each passage contained almost 150 words followed by matching and multiple-choice items.

\section{Pilot Study}

A number of 30 students with similar characteristics to that of the target sample were used for piloting the tests.

It took about 30 minutes for either test to finish. The Cronbach's alpha for reliability of the tests in the pilot study was estimated. The results indicated the reliability of 0.78 for reading comprehension test. This indicated that the instruments enjoyed high reliability estimate and were therefore appropriate for the purpose of the study. Based on the results of pilot study, some items of the test were modified to avoid confusion on the part of test takers. The piloting section indicated that the time necessary for taking the test was 30 minutes. 


\section{Procedure}

In order to answer the research questions, the following procedure was pursued.

The reliability of the Preliminary English Test (PET) was already piloted by Seyyedrezaie, Ghapanchi, and Seyyedrezaie (2013). The result indicated that it had a reliability of .91. In order to have a homogeneous group of participants, this version of the Preliminary English Test (PET) was administered to all the 225freshman students. And only those students whose scores were between one standard deviation above and below the mean of the normal distribution curve were chosen for the study. As a consequence, 200 learners were included as the participants in the study.

To reduce learners' anxiety and maximize learning, one face-to-face orientation was conducted for the online learners before the first session. One day before the first session, all participants were given a reading comprehension test in addition to the Strategy Inventory for Language Learners (SILL) as the pre-test. Accordingly, the same reading test and one scale were given to them as the post-test six weeks later after the participants finished five 90-minute sessions, one session per week. The rationale behind using the same test and scale in pre-tests and post-tests was to assure exactly comparable tests. Students were not given the correct answers after the pre-test. Besides, the interval (five weeks) between the pre-tests and post-tests was deemed long enough to control for any short-term memory effects.

During this instructional phase, 100 students in one group benefited from face-to-face instruction and 100 students in another group benefited from web-based instruction through Nicenet, because using the Nicenet course site did not require any special license or registration fees. The web-based learners used their own PCs and the Internet from home.

In the instructional phase, for the face-to-face learners, first, the researcher as an instructor informed the students upon the importance of strategic reading and made an attempt to define the concept of summarization strategy in theory and practice. But for the web-based learners, the students were given an instruction on the concept of summarization strategy which is available on the Nicenet. Teacher as a model tries to initiate using this strategy while reminding merits of this strategy in being effective readers. Then, the explicit instruction of the summarization strategy was given to the participants. Besides, both groups were provided with clear examples in order to grasp the usefulness of this strategy and learn how to apply it. After this step, the participants practiced what has been taught to them using various texts and tasks. After that, the teacher encouraged independent use of summarization strategy. Also, the teacher provided scaffolding until they became independent. So, for the face-to-face learners, the instructor provided support whenever necessary, while for the web-based learners, there is no opportunity for receiving the instructor's help whenever it is needed. They also assessed their own strategy use right after each practice session by monitoring their strategy use in addition to their understanding. To develop larger collection of strategies, the instructor asked the students to apply this strategy to new tasks. The students follow the instructional phase during five weeks of their educational semester in their reading class. Moreover, the participants take the comprehension test once as pretest before going through the instructional program and once after it as a posttest.

\section{E. Design}

The design of this study was a true-experimental design. The reason for choosing this design rested upon the fact that participants were randomly selected and during a 5 week course of treatment, they were given instruction on the summarization strategy to apply it to new task. Web-based and face-to-face instructions were independent variables and language learning strategies and reading comprehension were the dependent variables. Because all participants were between the age range of 18-24, the age of the participants was the control variable. Also, another control variable of the study was the language proficiency of the participants. As the researcher had no control over gender of the participants, gender was considered as the intervening variable.

\section{RESULTS AND DisCUSSION}

The results of the study are summarized in the following tables:

In order to answer to the research questions of the study, the results of the questionnaire and the reading comprehension test were discussed in relation to descriptive and inferential statistics.

Table 1 indicates descriptive statistics for the scores of the students on the SILL. In other words, the table shows minimum score, maximum score, mean, and standard deviation for the same number of participants in each group regarding their preferences for language learning strategies. 
TABLE 1:

DESCRIPTIVE STATISTICS FOR THE SCORES OF THE PARTICIPANTS ON THE SILL

\begin{tabular}{|c|c|c|c|c|c|c|c|c|c|c|c|c|}
\hline \multirow{2}{*}{$\begin{array}{l}\text { Strategy } \\
\text { Statistic }\end{array}$} & \multicolumn{2}{|l|}{ Memory } & \multicolumn{2}{|c|}{ Cognitive } & \multicolumn{2}{|c|}{ Compensation } & \multicolumn{2}{|c|}{ Metacognitive } & \multicolumn{2}{|c|}{ Affective } & \multicolumn{2}{|l|}{ Social } \\
\hline & $\begin{array}{l}\text { Web- } \\
\text { based } \\
\text { learners }\end{array}$ & $\begin{array}{l}\text { Face-to- } \\
\text { face } \\
\text { learners }\end{array}$ & $\begin{array}{l}\text { Web- } \\
\text { based } \\
\text { learners }\end{array}$ & $\begin{array}{l}\text { Face-to- } \\
\text { face } \\
\text { learners }\end{array}$ & $\begin{array}{l}\text { Web- } \\
\text { based } \\
\text { learners }\end{array}$ & $\begin{array}{l}\text { Face-to- } \\
\text { face } \\
\text { learners }\end{array}$ & $\begin{array}{l}\text { Web- } \\
\text { based } \\
\text { learners }\end{array}$ & $\begin{array}{l}\text { Face-to- } \\
\text { face } \\
\text { learners }\end{array}$ & $\begin{array}{l}\text { Web- } \\
\text { based } \\
\text { learners }\end{array}$ & $\begin{array}{l}\text { Face-to- } \\
\text { face } \\
\text { learners }\end{array}$ & $\begin{array}{l}\text { Web- } \\
\text { based } \\
\text { learners }\end{array}$ & $\begin{array}{l}\text { Face-to- } \\
\text { face } \\
\text { learners }\end{array}$ \\
\hline $\mathrm{N}$ & 100 & 100 & 100 & 100 & 100 & 100 & 100 & 100 & 100 & 100 & 100 & 100 \\
\hline MIN & 1.81 & 1.69 & 1.85 & 2.03 & 1.38 & 1.69 & 2.03 & 2.19 & 1.69 & 1.69 & 2.03 & 1.53 \\
\hline MAX & 4.69 & 4.86 & 4.53 & 4.69 & 4.53 & 4.53 & 4.58 & 4.81 & 4.84 & 4.69 & 4.74 & 4.69 \\
\hline MEAN & 3.19 & 3.32 & 3.20 & 3.09 & 3.30 & 3.29 & 3.31 & 3.57 & 3.12 & 3.20 & 3.20 & 3.15 \\
\hline STD & 0.67 & 0.76 & 0.58 & 0.69 & 0.67 & 0.73 & 0.69 & 0.65 & 0.71 & 0.64 & 0.75 & 0.75 \\
\hline
\end{tabular}

The first research question of the study stated that whether there is any significant difference between post-test scores of web-based learners and face-to-face learners with regard to their preferences for language learning strategies. In order to investigate this research question, an independent samples t-test was conducted. The results are summarized in Table 2.

TABLE 2:

INDEPENDENT SAMPLES T-TEST FOR WEB_BASED AND FACE_TO_FACE LEARNERS' PREFERENCES FOR LSSS

\begin{tabular}{|c|c|c|c|c|c|c|}
\hline & & \multicolumn{2}{|c|}{$\begin{array}{l}\text { Levene's Test for Equality of } \\
\text { Variances }\end{array}$} & \multicolumn{3}{|c|}{ T-test for Equality of Means } \\
\hline & & F. & Sig. & $\mathrm{t}$ & $\mathrm{df}$ & Sig. (2-tailed) \\
\hline \multirow{2}{*}{$\begin{array}{l}\text { LLSs } \\
\text { Average }\end{array}$} & Equal Variances Assumed & .231 & .635 & -1.178 & 200 & .243 \\
\hline & $\begin{array}{l}\text { Equal Variances Not } \\
\text { Assumed }\end{array}$ & & & -1.178 & 199.95 & .243 \\
\hline
\end{tabular}

As shown in Table 2, the average scores of the two groups were compared. As the table indicates, the existing significance value (.243) is larger than the significance level (.05). This result is similar to that of the comparison of pretest scores of two groups with regard to language learning strategies. As the result of pre-test scores revealed the existing significant value (.151) was larger than the significant level (.05). In other words, both of them indicated that there is no significant difference between the two groups of learners (web-based learners vs. face-to-face learners) with regard to their preferences for language learning strategies.

In fact, it should be considered that language learning strategies are applied more or less the same way by learners under different educational contexts; in other words, learning provided with web-based program is more self-directed and doesn't need any instruction to fit the assumed framework to the current teaching/learning issues. As a result, the selection and use of language learning strategies is not noticeably affected by the type of education system.

The result that language learning strategies scores of students did not change regarding the type of instruction the learners received is the same as the finding of Köymen (1990, cited in Kurt \& Gurcan, 2010)'s study. Köymen concluded that there was no significant difference between traditional higher education students' use of learning strategies and the learning strategies use of students attending online education. On the other hand, this finding is in contrast with Bar-Yam's (2003) finding revealing that the educational system under which the learners develop L2 communicative abilities influences the choice and use of learning strategies. Also, Carns and Carns (1991) reported the similar finding. These two research findings were different from the finding of the present study due to the fact that the students provided with training on learning strategies, while in the present study, no such training was given to the students. Regarding the research findings, it could be mentioned that without taking any training on strategies, there was no significant difference in the learning strategies of students regarding the type of instruction they received. In addition, it could also be stated that the strategy training received by students might result in a significant difference.

The second research question stated that whether there is any significant difference between pre-test and post-test scores of EFL students who were exposed to web-based and face-to-face instruction. In order to investigate this null hypothesis, a paired samples t-test was conducted. The results are summarized in Table 3.

TABLE 3:

A PAIRED SAMPLES T-TEST OF PRE_AND POST_TEST READING COMPREHENSION SCORES OF WEB_BASED AND FACE_TO_FACE LEARNERS

\begin{tabular}{|l|l|l|l|l|l|l|l|l|l|l|}
\hline Face-to-face group & \multicolumn{1}{|c|}{ Web-based group } \\
\hline & N & M & SD & t & p & N & M & SD & t & p \\
\hline Pretest & 100 & 115.10 & 18.80 & 2.10 & .01 & 100 & 70.8 & 9.39 & .89 & .38 \\
\hline Posttest & 100 & 120.85 & 20.14 & & & 100 & 70.1 & 9.65 & & \\
\hline
\end{tabular}

As the table shows, the existing significant value (.01) of face-to-face group is smaller than the significant level (.05). In other words, there is a significant difference between pre-test and post-test reading comprehension scores of EFL students on the basis of face-to-face instruction. On the other hand, for the web-based group, the mean almost decreased which does not necessarily indicate that there was no progress at all in this instruction. As the table shows, the existing significant value (.38) of web-based group is larger than the significant level (.05). In other words, there is no significant difference between pre-test and post-test reading comprehension scores of EFL students exposed to web- 
based instruction. As for this instruction, several aspects must be considered: the degree of familiarity students had with the Nicenet platform, the limited interaction they had with the instructor and the classmates, and the degree of motivation for this instruction.

The finding of a study conducted by Can, Saglam, Eristi, and Kurum (2007) indicated that students involving in the instructional activities without any Internet use are more successful than the students involving in Internet-based instructional activities supports the finding of the present study. On the other hand, the finding of the present study stand in contrast with the study carried out by Schutte (1999) which indicated that students taking education in multimedia classrooms were more successful than that of students taking education in traditional classrooms. The findings of the study are also in contrast with Harasim's (1995) results of the study that investigated 240 teachers and learners utilizing the internet for educational purposes. 90 percent of the 176 responses to a question about differences between learning in a computer-mediated environment and a traditional classroom, revealed that there were differences.

Although summarization strategy has a significant impact on post-test reading comprehension scores of EFL students on the basis of web-based and face-to-face instruction, it is the type of instruction which influences the effectiveness of summarization strategies.

\section{CONCLUSION}

Concerning the first null hypothesis stating that there is no significant difference between post-test scores of webbased learners and face-to-face learners regarding their preferences for language learning strategies, the findings of independent samples t-test indicated that the educational system has little effect on the way learners apply language learning strategies. That is, both groups of learners (web-based learners and face-to-face learners) had more or less the same ways in applying language learning strategies in their language learning process.

There are several factors why the findings of the present research were not supported by most of the findings of other studies (Schutte, 1999; Harasim, 1995). The finding of this study is somehow different from Namlu's (2003) finding who found a significant increase in the learning strategies of the students who were in the experimental group taking training on learning strategies. The difference between finding of this study and Namlu's study may be because of the changes in the participants (age, gender, level) or in the number of participants in both studies. Another factor that might count for the difference between the findings of the studies may be caused by the kind of interaction between the teacher and the students in the two studies. In addition, it may be because of the length of the study. This study took 6 weeks but Namlu`s (2003) study lasted a semester.

Considering the second research question which deal with investigating the difference between pre-test and post-test reading comprehension scores of EFL students on the basis of web-based and face-to-face instruction, the obtained findings through paired samples t-test revealed that there is a significant difference between pre-test and post-test reading comprehension scores of EFL students on the basis of face-to-face instruction. In contrast, there is no significant difference between pre-test and post-test reading comprehension scores of EFL students on the basis of webbased instruction. Additionally, although summarization strategy has a great impact on post-test reading comprehension scores of EFL students in both groups, it is the type of instruction which influence the effectiveness of summarization strategies.

\section{REFERENCES}

[1] Adegbile, J. A., \& Oyekanmi, J. O. (2009). Assessment of support facilities available to degree programme distance learning students in the Southwestern Nigerian universities. Educational Research and Review, 4(2), 42-47.

[2] Aguinis, H., \& Kraiger, K. (2009). Benefits of training and development for individuals and teams, organizations, and society. Annual Review of Psychology, 60, 451-474.

[3] Anderson, T. H., \& Armbruster, B. B. (1984). Content area textbooks. In R. C. Anderson, J. Osborn \& R. J. Tierney (Eds.), Learning to read in American schools (pp. 193-224). Hillsdale, NJ: Erlbaum.

[4] Asgari, A., \& Mustapha, G. B. (2011). The type of vocabulary learning strategies used by ESL learners in university Putra Malaysia. English Language Teaching, 4(2), 84-90.

[5] Beethman, H. (2003). Embedding learning technologies: Lessons for academic developers. Educational Developments, 4(4), 46-53.

[6] Carns, A. W., \& Carns, M. R. (1991). Teaching study skills, cognitive strategies and metacognitive skills through selfdiagnosed learning styles. ASCA School Counselor, 38, 341-346.

[7] Cohen, A. D. (1998). Strategies in learning and using a second language. London: Longman.

[8] Doctorow, M. J., Wittrock, M. C., \& Marks, C. B. (1978). Generative processes in reading comprehension. Journal of Educational Psychology, 70, 109-118.

[9] Dreyer, C., \& Nel, C. (2003). Teaching reading strategies and reading comprehension within a technology-enhanced learning environment. System, 31, 349-365.

[10] Graham, S., \& Hebert, M. A. (2011). Writing to read: A meta-analysis of the impact of writing and writing instruction on reading. Harward Educational Review, 81, 710-744.

[11] Harasim, L. (1995). Learning networks: A field guide to teaching and learning online. Cambridge, MA: The MIT Press.

[12] Hasanpour, M. (1999). Science student's use of language learning strategies and its relation to motivation, attitude, and gender. Unpublished M.A. thesis, Islamic Azad University of Shiraz, Iran.

[13] Khan, B. H. (Ed.). (1997). Web-based instruction. Englewood Cliffs, NJ: Educational Technology Publications. 
[14] Kurt, A. A., \& Gürcan, A. (2010). The comparison of learning strategies, computer anxiety and success states of students taking web-based and face-to-face instruction in higher education. Procedia - Social and Behavioral Sciences, 9, 1153-1157.

[15] Lam, M. (2009). Effectiveness of web-based courses on technical learning. Journal of Education for Business, 84(6), $323-331$.

[16] Littlewood, W. (1996). Autonomy: An anatomy and a framework. System, 24(4), 427-435.

[17] Lock, J. V. (2006). A new image: Online communities to facilitate teacher professional development. Journal of Technology and Teacher Education, 14 (4), 663-678.

[18] Luthans, F., Avey, J. B., \& Patera, J. L. (2008). Experimental analysis of a web-based training intervention to develop positive psychological capital. Academy of Management Learning \& Education, 7(2), 209-221.

[19] Namlu, A. G. (2003). The effect of learning strategies on computer anxiety. Computers in Human Behavior, 19, 565-578.

[20] Olson, T. M., \& Wisher, R. A. (2002). The effectiveness of web-based instruction: An initial inquiry. International Review of Research in Open and Distance Learning, 3(2). Retrieved January 24, 2013, from http://www.irrodl.org/content/v3.2/olsen.html.

[21] O’Malley, J. M., \& Chamot, A. U. (1990). Learning strategies in second language acquisition. Cambridge: Cambridge University Press.

[22] Oxford, R. (1990). Language learning strategies: What every teacher should know. New York: Newbury House.

[23] Oxford, R. L., \& Nyikos, M. (1989). Variables affecting choice of language learning strategies by university students. The Modern Language Journal, 73(3), 291-300.

[24] Pakzadian, M., \& Eslami Rasekh, A. (2012). The effects of using summarization strategies on Iranian EFL learners' reading comprehension. English Linguistics Research, 1(1), 118-125.

[25] Palinscar, A. S., \& Brown, A. L. (1984). Reciprocal teaching of comprehension-fostering and comprehension monitoring activities. Cognition and Instruction, 1, 117-175.

[26] Paris, S. G., \& Lindauer, B. K. (1982). The development of cognitive skills during childhood. In B. R. Wolman (Ed.), The handbook of developmental psychology (pp. 333-349). Englewood Cliffs: Prentice Hall.

[27] Pearson, P. D., \& Fielding, L. (1991). Comprehension instruction. In R. Barr, M. L. Kamil, P. Mosenthal, \& P. D. Pearson (Eds.), Handbook of Reading Research (pp. 815-860). White Plains, NY: Longman.

[28] Senn, G. J. (2008). Comparison of face-to-face and hybrid delivery of a course that requires technology skills development. Journal of Information Technology Education, 7, 267-283.

[29] Seyyedrezaie, Z. S., Ghapanchi, Z., \& Seyyedrezaie, M. S. (2013). Relationship between EFl learners' computer anxiety and their preferred feedback method(s) in writing. International Journal of Basic Sciences \& Applied Research, 2(1), 174-182.

[30] Schutte, J. G. (1999). Virtual teaching in higher education: The new intellectual superhighway or just another traffic jam?, Retrieved January 13, 2013, from http://www.csun.edu/sociology/virexp.html.

[31] Tahririan, M. H. (1996). Developing Reading Proficiency I. Tehran, Payam-e-Noor University Press.

[32] Wenden, A. L., \& Rubin, J. (Eds.). (1987). Learner strategies in language learning. Englewood Cliffs, NJ: Prentice Hall.

[33] Wittrock, M. C., \& Alesandrini, K. (1990). Generation of summaries and analogies and analytic and holistic abilities. American Educational Research Journal, 27, 489-502.

[34] Yazdani Moghaddam, M., Seyyedrezaie, S. H., Rajabi, M., \& Barani, Gh. (2008). Live reading. Tehran, Rahnama Press.

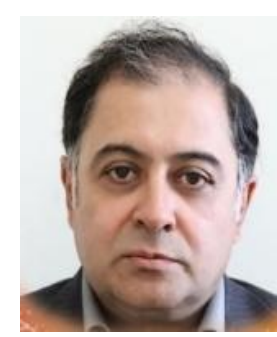

Behzad Ghonsooliy is a professor at Ferdowsi Universityof Mashhad. He got his Ph.D in applied linguistics from Stirling University. He has published several books and articles in different local and international journals. His main research interests are language testing, ESP, and translation studies.

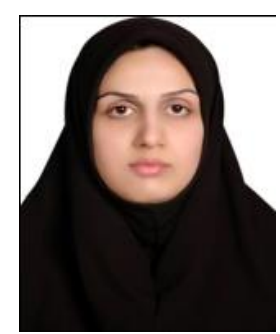

Zari Sadat Seyyedrezaie received her BA in English language and literature from Zahedan University, Iran. Then she received her MA in TEFL from Islamic Azad University, Science and Research Branch in Iran. She started her Ph.D at the University of Mashhad in 2012. She has presented some papers in International conferences in different countries and also published some papers in international journals. Her major areas of interest are English testing, evaluation, and language teaching methodology. 